\title{
To Explore Hotel Service Factors Effect on Increasing Tourist Loyalty-Malaysia Evidence (Preliminary Study)
}

\author{
*Hossein Nezakati, Yousef Keshavarz \\ Universiti Putra Malaysia (UPM), Serdang, Selangor, Malaysia \\ *hossein@econ.upm.edu.my
}

\begin{abstract}
Tourism industry has become more important in the global economy because it has the fastest growth in recent years. Based on United nation world tourist organization, Malaysia is the $9^{\text {th }}$ country in the world and $3^{\text {rd }}$ country in Asia in attracting tourists with 24.6 million one in 2010. Hotels play important role by providing quality service to customers and enhancing their loyalty. Rapid growth among hotels in tourism industry make hotels to recognize services as an important factor attracting more tourists, hence those are profitable. Therefore this primary study tries to start finding out relationship between important aspects of services such as process, place and personnel in hotels with tourist length of staying and frequency intention to revisit. Other research objectives are to investigate the effect of tourist's length of stay and frequency intention to revisit on tourist loyalty.
\end{abstract}

Keywords: Malaysian hotels, Service quality, Customer loyalty, Tourist loyalty

\section{Introduction}

Stank et al., (1999) defined service performance as the level of a service which categorized into two important level: operational performance which is related to physical aspect of service and relational performance which is related to the service delivery process. Parasuraman et al. (1988) provided the SERVQUAL as a multi-item scale to assess customer perception of quality of provided service. This scale has five aspects: tangible, reliability, responsiveness, assurance and empathy which can provide operational definition of service quality. Therefore modified scales based on specific hotels are suitable for operational definition for service quality. Valuable model is provided by Kano (1984) to help analysis customer satisfaction. This model include classifications: attractive quality (A), one dimensional quality (0), must be quality (M), indifferent quality (I) and reverse quality(R). Skogland \& siguaw (2004) provided an useful instrument to evaluate customer loyalty in hotel industry. Loyalty based on Stank et al. (1999) is defined as a customer attitude to the service. They believed that customer attitude is not formed only by a specific interaction, but cumulative experiences are involved in its formation (Kim et al., 2007). Based on Hawkins \& Chan (2010) customer loyalty is defined as "customer intention or actual behavior to repeatedly purchase certain product or services". Hsieh \& Lin (2010) showed that international hotels are categorized as four to five stars hotels. Chiang et al (2004) and Hawang \& Chang (2003) found that chain hotels are more efficient than independent ones. The purpose of this primary study is to explore the relationship between services provided by hotels (tourists perceptions of quality of these services) and loyalty in Malaysian hotel industry. Based of these objectives the quastion of the study is definded include: Which factors of service provided by hotels are related positively to customer loyalty in Malayysian hotel industry? The Malaysian hotel industry will enjoy the advantages of this study by underestanding the priority of their customers about services dementions in hotels and learn this to thier employees to enhance the customer satisfaction henc their loyalty.

\section{Literature Review}

There are several studies about service quality and its affect on customer satisfaction (Hsieh et al., 2008; Senga et al.; 2007 and Tsung et al., 2008) especially some research provided information about the effect of hotel's services on visitors (Barros \& Mascarenhas 2005; Hawang \& Chang, 2003 and Wang et al., 2006). They tried to realize important aspects of service in different companies by which customers are satisfied or not. Some models are designed to evaluate service such as SERVQUAL provided by Parasoraman (1988). They 
defined quality as the gap between customer's expectation and perceptions. Service quality is the most important part of hotels to be profitable and to grow in tourism industry (Senga et al., 2007). Hsieh (2008) believed that dimensions of service quality provided by Parasoraman and his college must be concerned she argued that this aspects are reliability, responsiveness, competence, access, courtesy, communication, credibility, security, understanding and knowing the customer and tangible. Amjad \& Mamoun (2011) believe three factors in hotel services are important to attract tourists to be loyal, reputation building, nonverbal communication and customer service culture. According to Tsung et al. (2008) enhancing facilities and requirements for customers in these days, which called as customers-based service, help to raise customer loyalty. Physical evidence plays vital role to provide qualified service in hotels and as Berry et al. (2007) argued, the quality of services is not determined only by one aspect of that and whole service package is necessary. Although there is not agreement about the relationship between the constructs of service quality with customer satisfaction, both of them affect future tourist selection (Tian \& Crompton, 2003). In addition, personnel play the vital role to improve customer's satisfaction in hotels. Simon (2000) believes that interaction with service personnel is affect guest satisfaction. He argues that if tourists perceive that employees' behavior is unethical, it influences the whole assessment of the hotels' service and they will downgrade the quality of received service. So, ethical standard for employees plays the important role in presenting warm equitable and good service for all guests. Although tourists prefer to receive qualified service, authenticity of displayed service is more important and it affects on customer's satisfaction Grandey et al. (2005).

Therefore based on previous research it is clear that service quality is very important for both customers and hotel managers to have long term relationship with together. So in this research try to realize the affects of five important aspects of service quality includes process, personnel, place switching cost and past experience on customer length of stay and revisit the hotel and finally try to realize the affect of these factors on customer loyalty. To analysis service quality previous models and theories must be concerned such as: GAP (Cronin \& Tylor, 1994), SERVQUAL, DEA (Kao, 2009) and KANO (Kano, 1984). These models and theories are useful for this research and try to merge all these models to obtain model and framework which is suitable for studying in Malaysian hotels. It is argued that by providing more qualified services in hotel they can attract more tourists or encourage them to stay more or rebook this hotel for next time. On other word, by providing more qualified service they make tourists loyal to their hotel hence improve their profitability and help country to attract more tourist and receive to predicted plan. In fact $78 \%$ of executives in western countries and Japan believe that the key factor in hotel to compete with others is service improvement (Chen, 2005). Since 1920s when the first service research had started (Atilla, 2006), so many researches has carried out about service quality and customer loyalty (such as: Smith and Lewis, 1989; Quinn and Humble, 1993; and Sara T. et al., 2012), however, from the literature review it is realized that there is a little researches have designed to investigate the relationship between service quality and customer loyalty in hotels specially in Malaysian hotels.

\section{Conceptual Model and Hypothesis}

\section{Figure 1: Conceptual Model}

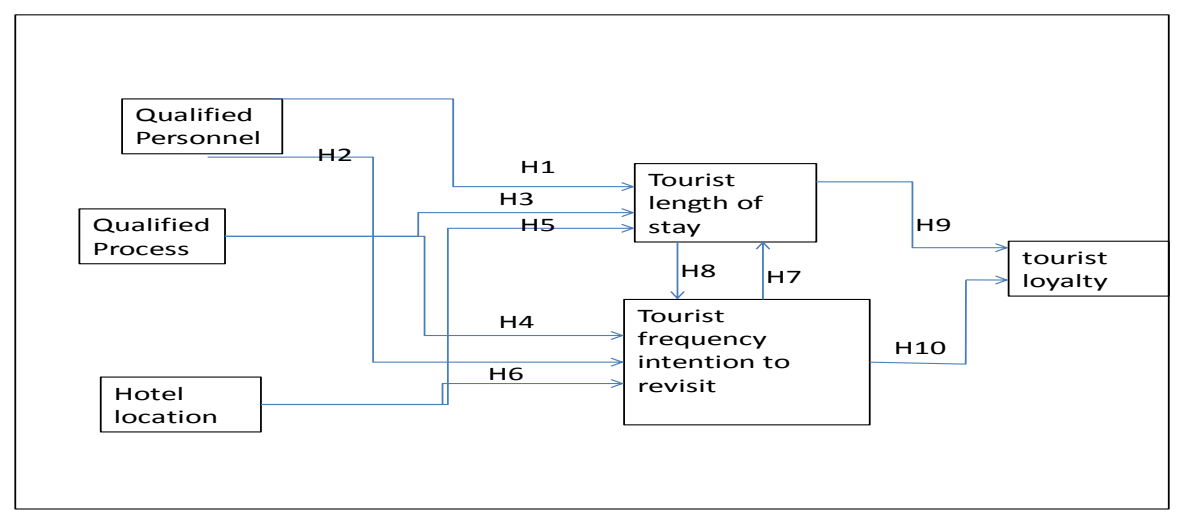


H1: Qualified personnel have significant effect on tourist length of staying in the hotel.

H2: Qualified personnel have significant effect on tourist's decision making on frequency intention to revisit the hotel.

H3: Qualified process has significant effect on tourist length of staying in the hotel.

H4: Qualified process has significant effect on tourist frequency intention to revisit the hotel.

H5: Hotel location has significant effect on tourist length of staying in the hotel

H6: Hotel location has significant effect on tourist frequency intention to revisit the hotel.

H7: Tourist frequency intention to revisit has significant effect on tourist length of staying in the hotel.

H8: Tourist length of staying has significant effect on tourist frequency to revisit the hotel.

H9: Tourist length of staying has significant effect on tourist loyalty.

H10: Tourist frequency intention to revisit has significant effect on tourist loyalty.

\section{Methodology}

This study intends to describe the current status of service provided by hotels in Malaysia and their effects on customer loyalty. As this study has dealt with variables which is determined in the first step of research the quantitative method will be used. Because of the nature of the problem, cross-sectional survey will used and data will collected at one point of time. With the use of quantitative method, the validity and reliability of the findings can be enhanced and interpreted results can be generalized to other members of tourist society. Therefore, this study by purpose and method is classified as a conventional method in which according to Strauss et al. (1998) relies on assumption substantive body of research finding about buyer behavior. Variables in conventional method could be incorporate in to a standard regression analysis (Mahoney, 2000).

Population, sample, and participants: The population is hotels' customers in Malaysia; those are the customers of hotels' accommodations and spend at least one night in on Malaysian hotels. The sample is selected based on Sue Greener (2008) attitude who believe the sample size must be more than 30 and less than 1000, therefore in this study uses the formula of "Number of samples for an infinitely large population" and select 500 respondents as sample. In this study like other social studies to determine the number of random samples needed for a $95 \%$ as confidence interval. The sampling design for this study is multistage in which, as it is provided by Peter and Howard (2010), the researcher first identifies clusters (groups) and then samples within them.

\section{Conclusion}

This survey study tries to investigate the relationship important aspects of services such as process, place and personnel in hotels with customer's length of stay and revisit and to investigate the effect of customer's length of stay and revisit on customers loyalty. Studying previous models such as SERVQUAL, Gap and Kano, it tries to emerge them and design new framework for hotel industry in Malaysia and endeavor to realize the relationship between variables which are mentioned above.

\section{References}

Atilla, A. (2006). Measuring service quality in the hotel industry: A study in a business hotel in Turkey. Hospitality Management, 25, 170-192.

Amjad A. E. \& Mamoun, A. (2011). Consequences of Customer Service Skills: An Integrated Model. International Journal of Service Standards, 7(1), 50-76.

Barros, C. P. \& Mascarenhas, M. J. (2005). Technical and allocative efficiency in a chain of small hotels. International Journal of Hospitality Management, 24(3), 415-436.

Berry, L. L. \& Bendapudi, N. (2007). Health care: a fertile field for service research. Journal of Service Research, $10(2), 11-22$.

Chen, H. L. (2005). Relationship between guest perception of service quality and customer loyalty in the hotel industry in south Florida, unpublished dissertation, Lynn University.

Chiang, W. E., Tsai, M. H. \& Wang, L. S. M. (2004). A DEA evaluation of Taipei hotels. Annals of Tourism Research, 31(3), 712-715. 
Cronin, J. J. \& Taylor, S. A. (1994). SERVPERF versus SERVQUAL: Reconciling performance-based and perceptions-minus-expectations measurement of service quality. Journal of Marketing, 58(1), 125137.

Grandey, A., Fisk, G. \& Steiner, D. (2005). Must service with a smile be stressful? The moderating role of personal control for U.S. and French employees. Journal of Applied Psychology, 90, 893-914.

Greener, Sue (2008). Business research methods, Ventus publishing APS. Copenhagen, 47-51.

Hawkins, R. \& Chan, E. S. W. (2010). Attitude towards EMSs in an international hotel: an exploratory case study. International Journal of Hospitality Management, 29(4), 641-651.

Hsieh L. F., Lin L. H. \& Lin, Y. Y. (2008). Service quality measurement architecture for hot spring hotel in Taiwan. Tourist management journal, 2, 429-438.

Hsieh L. F. \& Lin L. H. (2010). A performance evaluation model for international tourist hotels in Taiwan-An application of the Relational network DEA. International Journal of Hospitality Management, 29, 1424.

Hwang, S. N. \& Chang, T. Y. (2003). Using data envelopment analysis to measure hotel managerial efficiency change in Taiwan. Tourism Management, 24(4), 357-369.

Kao, C. (2009). Efficiency decomposition in network data envelopment analysis: a relational model. European Journal of Operational Research, 192(3), 949-962.

Kano, N., Seraku, N., Takahashi, F. \& Tsjui, S. (1984). Attractive Quality And Must-Be Quality. Hinshitsu, 147156.

Kim, J. K., Jeong, I. J., Park, J. C., Park, Y. J., Kim, C. G. \& Kim, T. H. (2007). The impact of network service performance on customer satisfaction and loyalty: High-speed internet service case in Korea. Expert Systems with Applications, 32, 822-831.

Mahoney, J. (2000). Rational Choice Theory and the Comparative Method: An Emerging Synthesis? Studies in Comparative International Development, 35(2), 83-94.

Parasuraman, A., Zeithaml, V. A. \& Berry, L. L. (1988). SERVQUAL: A multiple item scale for measuring consumer perceptions of service quality. Journal of Retailing, 64(1), 13-40.

Peter, L. \& Howard, D. J. (2010). The dissertation: from beginning to end, Oxford University Press, Inc.,120121.

Quinn, M. \& Humble, J. (1993). Using service to gain a competitive edge -the PROMPT approach. long range planning, 26(2), 31-40.

Sarah, T., Carola, R. \& Kim, Y. (2012). Determinants of customer loyalty and purchasing behavior for fullservice and limited-service hotels. International Journal of Hospitality Management, 31, 319-328.

Senga, B., Sutherland, J. \& Siobhan, D. (2007). Are hotels serving quality? An exploratory study of service quality in the Scottish hotel sector. Tourism Management, 28, 1006-1019.

Simon, W. C. K. (2000). Tourists' perceptions of hotel frontline employees' questionable job-related behavior. Tourism Management, 21, 121-134.

Skogland, I. \& Siguaw, J. A. (2004). Are your satisfied customers loyal? Cornell hotel and restaurant administration quarterly, 45, 221-234.

Smith, A. M. \& Lewis, B. R. (1989). Customer care in financial service organizations. International Journal of Bank Marketing, 7(5), 13-22.

Stank, T. P., Goldsby, T. J. \& Vickery, S. K. (1999). Effect of service supplier performance on satisfaction and loyalty of store managers in the fast food industry. Journal of Operations Management, 17, 429-447.

Strauss, A. L. \& Corbin, J. M. (1998). Basics of Qualitative Research: Techniques and Procedures for developing Grounded Theory, Sage Publications, Inc., 10-12.

Tsung, Y. C., Chia, L. H. \& Mei, C. C. (2008). A fuzzy multi-criteria decision model for international tourist hotels location selection. International Journal of Hospitality Management, 27, 293-301.

Tian, C. S. \& Crompton, J. L. (2003). A conceptualization of the relationships between service quality and visitor satisfaction, and their links to destination selection. Leisure Studies, 22, 65-80.

Wang, F. C., Hung, W. T. \& Shang, J. K. (2006). Measuring the Cost Efficiency of International Tourist Hotels in Taiwan. Tourism Economics, 12(1), 65-85. 